J. Lake Sci. (湖泊科学), 2012, 24(1):9-16

http: //www. jlakes. org. E-mail : jlakes@niglas.ac.cn

(C) 2012 by Journal of Lake Sciences

\title{
太湖流域空间开发适宜性分区与失衡性评估"
}

孙 伟

(中国科学院南京地理与湖泊研究所,南京 210008)

摘 要: 随着发达地区经济社会的快速发展, 建设用地急剧扩张, 改变地表下垫面水文条件, 成为导致区域水环境不断恶 化的重要因素,并引发一系列的资源环境问题. 为了促进资源环境与经济社会均衡发展,近年来地理学界开展了大量空 间开发功能分区和适宜性分区的研究, 为区域空间管理和建设用地调控提供科学依据,但是这些研究大多以单一行政区 为对象,缺少流域等跨行政区的自然地理单元的分区研究,忽视了流域经济社会发展与资源环境保护的整体性. 为此, 本 文在借鉴相关分区研究的基础上,以太湖流域为例,探讨了流域单元空间开发适宜性分区指标选择与综合评价等技术方 法,将太湖流域划分为高适宜区、中等适宜区、低适宜区和不适宜区等四种类型,并采用数据包络分析方法,探讨了建设 用地配置规模与空间开发适宜性的对应关系和均衡程度, 据此判断流域空间开发的失衡状态.

关键词: 空间开发适宜性分区;空间失衡;太湖流域

\section{Regionalization of spatial development suitability and evaluation of spatial unbalance in Taihu Basin}

\section{SUN Wei}

( Nanjing Institute of Geography and Limnology, Chinese Academy of Sciences, Nanjing 210008, P. R. China)

\begin{abstract}
Along with the rapid development in developed areas, rapid expansion of construction land has caused changes of underlying surface hydrological conditions which could be an important factor for deterioration of water environment, and trigger series of environmental problems. In recent years, in order to coordinate the relationship between environment and economic development, many studies on spatial potential development regionalization have been carried out, which provides scientific basis and regulations for regional government on construction sprawl control. But most of these studies chose single administrative region as object, which lacks geographical unit of regional zoning across various administrative, and neglects the integrity of development with resource protection. The present study, based on existing related regionalization method, discusses the method of choosing indicators and evaluation in the scale of basin area. As a case study, Taihu Basin is divided into four types: high suitable areas, medium suitable areas, low suitable areas and non-suitable areas. By using data envelopment analysis method, the present study has explored the correspondence relationships between construction land, resource environmental capacity and development potential, and the unbalance situation of construction land distribution is assessed. The result can provide scientific basis for coordinating economic development and natural resources management, and making polices of space governance.
\end{abstract}

Keywords: Spatial potential development regionalization; spatial unbalance; Taihu Basin

流域作为一种特殊的自然地理单元,其内部土地利用变化会改变流域下垫面水文特性,容易引发一系 列的水资源、水灾害和生态环境问题,主要表现为下游洪水灾害加剧、水环境恶化、水资源短缺、湿地退化 等 ${ }^{[1]}$,特别是位于我国东部的大部分流域地区, 经济社会发展取得了巨大成就, 但是, 过度依赖资源占用和 粗放开发导致流域生态环境污染与恶化趋势明显,尤其在一些跨省市的流域开发过程中存在着人和自然之 间、区域之间不尽协调的矛盾 ${ }^{[2-3]}$. 因而,合理配置人类空间开发活动, 满足流域发展所要求的经济效率和生 态安全,促进流域开发与资源环境供给能力的空间均衡, 成为关系到流域科学管理和持续发展的关键

* 国家科技支撑计划项目(2008BAH31B06) 和国家自然科学基金项目 (41130750) 联合资助. $2011-04-13$ 收稿; 2011-07-14 收修改稿. 孙伟,男,1980 年生,博士, 助理研究员;E-mail : wsun@ niglas. ac. cn. 
问题 ${ }^{[4]}$.

一般来说,每个地区在经济、社会和生态等方面的发展水平差异, 取决于空间区位的供给能力, 空间均 衡可以理解为经济社会活动分布与空间区位供给能力相协调. 如果空间开发与其供给能力及保护要求不相 匹配, 就会导致地区经济、社会、资源、环境不相协调, 出现空间失衡 ${ }^{[5]}$. 因此, 许多研究开始将自然生态和资 源环境要素纳人区域开发供给能力差异的分析框架之中, 认为均衡的空间开发模式必须建立在适宜性评价 基础之上 ${ }^{[6-8]}$. 因而开展空间功能分区和适宜性分区研究, 判断区域空间开发的供给能力, 引导建设用地开 发等活动在空间上合理配置成为近年来地理学和土地管理学的研究热点. 相关研究还以省、市行政区为实 证探讨了分区的指标选择、单元设置、评价方法等,形成了相对成熟的方法体系 ${ }^{[9-11]}$. 但是, 现有研究大多基 于闭合行政区, 对于跨省区的分区研究, 特别是以流域等地理条件和资源环境具有高度相关性的自然单元 为对象的分区研究较少,对于流域内不同行政区空间开发条件评估及管治政策制定缺乏系统的方法支撑. 另一方面, 现有的空间开发强度格局与各地区的资源环境和经济社会发展条件是否匹配, 空间开发过度或 不足等失衡程度该如何评估, 现有研究方法也较为欠缺, 因此开展空间失衡状态定量评估方法的研究十分 必要.

综上所述, 本文以太湖流域为例, 探讨流域单元空间开发适宜性分区指标选择及综合评价方法, 通过将 分区与空间开发强度配置格局进行对比分析, 判断流域空间开发的失衡程度, 通过引人 DEA(数据包络分 析) 方法建立开发强度与资源环境承载力和发展潜力间的均衡评估模型 ${ }^{[12-14]}$, 探讨各单元是否存在建设用 地开发过度或不足等失衡问题, 据此提出空间开发调控与优化建议, 以期为流域空间管治与协调发展提供 科学依据.

\section{1 研究区域概况}

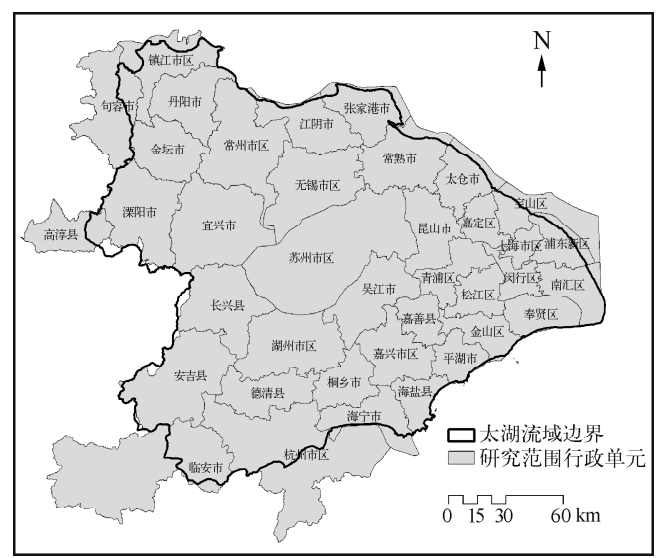

图 1 研究区域范围

Fig. 1 The boundary of study area

太湖流域地处长江三角洲的南翼, 总面积约 3.69 $\times 10^{4} \mathrm{~km}^{2}$. 考虑到分区单元的完整性和数据可获性, 除 太湖流域在安徽省境内零星分布的山地外, 本文将流 域所涉的 38 个县、市、区全部纳人实证区域, 行政范围 跨上海市、江苏省和浙江省 (图 1), 总面积约 $4.44 \times$ $10^{4} \mathrm{~km}^{2}$, 其中湖泊水面面积 $0.61 \times 10^{4} \mathrm{~km}^{2}$, 河道总长约 $12 \times 10^{4} \mathrm{~km} .2009$ 年末, 总人口约 5438 万人, 占全国总 人口的 4\%, 地区生产总值达到 $3.9 \times 10^{12}$ 元, 约占全国 生产总值的 $12 \%$, 有近 10 个县市人均 GDP 达到 10000 美元以上.

快速的工业化和城市化进程在推动经济社会发 展取得巨大成就的同时, 也带动太湖流域土地利用 格局剧烈变化, 对太湖及其流域的生态环境产生较 大影响. 各级政府通过实施一系列生态清淤、动力换 水、生态修复等环境整治工程, 对改善太湖水质起到 了重要作用 ${ }^{[15-17]}$. 但太湖及流域其他水体水质并没 有得到明显的改善, 2009 年, 太湖有 $73.9 \%$ 的水域为劣 V 类, 富营养化程度持续加重; 太湖流域 99 个重 点水功能区中, 水质达标个数仅有 28 个, 达标率仅为 $28.3 \%$ (1) 根据 2011 年 1 月最新的流域水质监测结果, 33 个跨省界河流缓冲区中仅有 7 个水质达标, 达标率为 $21.2 \%$ (2). 太湖流域建设用地快速扩张和分散布局是 引起水质恶化的主要原因之一. 根据 TM 遥感影像解译, 2007 年太湖流域建设用地面积已达到 $7162.4 \mathrm{~km}^{2}$, 开发强度达到 $16.1 \%$, 接近 1985 年开发强度的两倍(图 2). 苏州、无锡、湖州等一些生态较

(1) 太湖流域管理局. 太湖健康报告 2009,2010 .

(2) 太湖流域管理局. 太湖流域及东南诸河省界水体水资源质量状况通报,第 164 期,2011. 
为敏感的沿湖城市建设用地增长速度甚至高于流域 建设用地扩张的平均水平,各行政区均以自身经济发 展为出发点, 同时进行大规模建设用地开发, 结果导 致建设用地分散无序扩张, 破坏原有水系格局和交换 的能力, 降低水环境容量和对污染物的稀释、净化和 吸纳能力.

可见, 湖泊水质的根本好转和生态健康的修复, 不 仅限于湖泊水体自身污染的修复,还要从流域的综合 调控和管理方面进行减排截污 ${ }^{[18]}$. 因此, 既要满足流域 经济社会发展需求, 又要科学保护流域生态系统, 还要 合理开发利用土地资源和环境容量资源, 除了加强研 究湖泊本身的科学问题外, 还必需进行流域空间开发 分区调控与管制,才能逐步实现流域经济与资源环境 均衡发展的目标.

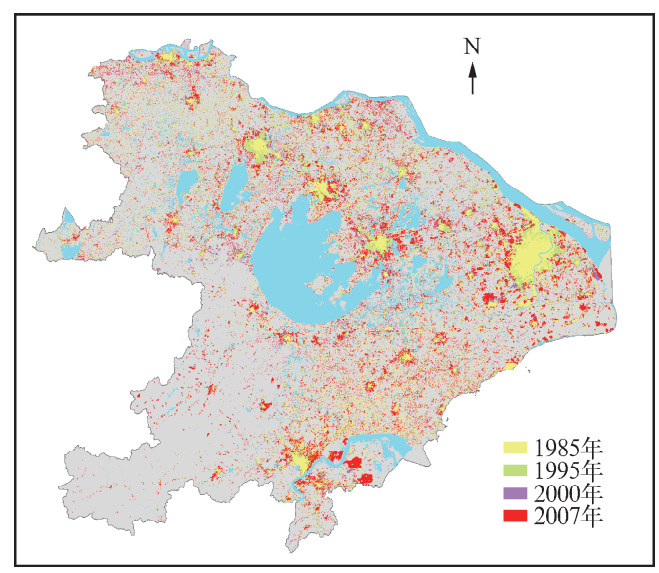

图 2 1985-2007 年太湖流域建设用地扩展

Fig. 2 Construction land changes from 1985 to 2007

\section{2 空间开发适宜性分区}

考虑到研究方案的现实指导性和操作性以及数据的可获性, 本文选取上海市城区、江苏和浙江地级市 市区和县 (县级市、上海市郊区) 为基本空间评价单元,共计 38 个.

\section{1 指标体系}

借鉴主体功能区和相关研究,结合太湖流域自然地理条件和经济社会发展特征, 从资源环境承载力和 发展潜力两方面构建分区指标体系. 其中, 重要生态功能区根据相关专项规划, 结合遥感影像图、地形图综 合划定; 灾害风险数据源自上海市、江苏省和浙江省灾害防治规划; 水资源丰度根据各市 2000-2008 年水资 源公报结合专家经验综合确定; 土地利用数据通过 1985、1995、2000 年 TM 和 2007 年 SPOT4 遥感影像解译 提取; 经济社会发展数据来自各省市 2009 年统计年鉴及有关专项年鉴; 交通优势度数据来自长三角综合交 通体系规划及各省市相关综合交通规划.

资源环境承载力是区域自然生态与资源环境条件对于经济社会发展的支撑能力, 主要通过生态重要 性、灾害易损性、水和土地资源供给保障程度四个方面来评价. 生态重要性主要通过各级各类重要生态功能 保护区面积大小来确定,主要包括水源地、滩涂湿地、丘陵山地、重要河湖水面、自然保护区、森林公园、风景 名胜区、地质公园、生态公益林等. 其中, 各类重要生态功能保护区的核心区、浙江南部 (不含湖州和嘉兴两 市) 海拔 $500 \mathrm{~m}$ 以上的山地、江苏和上海以及湖州和嘉兴两市海拔 $200 \mathrm{~m}$ 以上的山地划为极重要生态功能 区; 各类重要生态功能区的缓冲区、浙江南部海拔 $200 \sim 500 \mathrm{~m}$ 之间的山地、江苏和上海以及湖州和嘉兴两市 海拔 $50 \sim 200 \mathrm{~m}$ 之间的山地划为重要生态功能区; 未划人上述功能区的山体和水面作为较重要生态功能区, 根据各级生态功能区占评价单元面积比例, 确定各单元的生态重要性指数. 灾害易损性评价主要选取自然 生态系统结构、功能脆弱、抗御区域开发等外力干扰能力较低的地质灾害和自然灾害影响区判定,主要包括 地面沉降、洪涝和台风风险等. 按照各灾害风险区占所在行政区单元面积比例,确定各行政区灾害易损性指 数. 根据各地区无工程措施条件下水资源获取规模和难易程度, 确定长江沿岸地区水资源供给保障条件最 好, 其次是苏南及湖州等地区, 嘉兴虽靠近太湖, 但是水质性缺水问题较为突出, 水资源供给保障程度相对 较差 (图 3). 土地资源供给保障主要考虑可供开发土地资源占比, 即各单元国土面积减去不适宜开发的重要 生态功能区剩余土地占全部国土的比例.

发展潜力用以反映特定空间工业化和城市化发展的经济社会支撑条件, 主要通过经济发展水平、人口 集聚度、科技教育水平和交通优势度来反映. 其中, 经济发展水平主要通过投人产出水平评价,具体包括人 均 GDP、劳动生产率(单位从业人员 GDP 产出)、生产性投资回报率和单位建设用地二三产业产出来反映; 人口集聚度主要通过人口密度和人口流动强度 (外来人口占总人口比例) 来反映; 科技教育水平主要通过平 均受教育年限和亿元 GDP 专利授权数来反映; 交通优势度主要通过各单元中心到上海的时间可达性和交通 


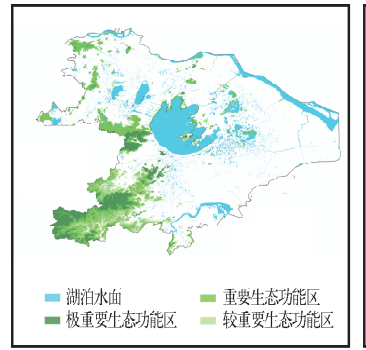

重要牛.态区.分布

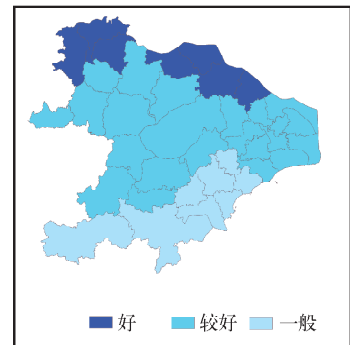

水资源供给保障
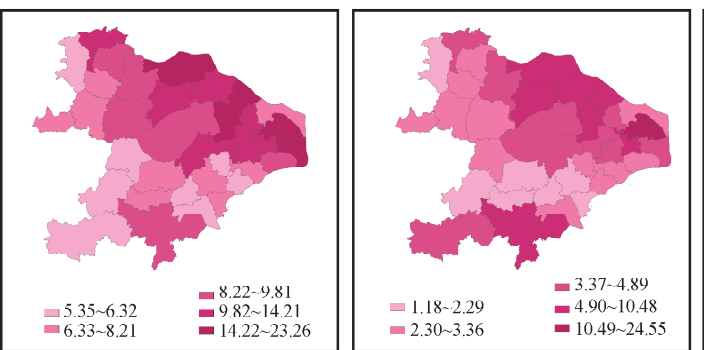

劳动生产率/(万元 / 人) 单位建设用地非农产出/(亿元 $\left./ \mathrm{km}^{2}\right)$ 人口密度/(人/ $\left.\mathrm{km}{ }^{2}\right)$

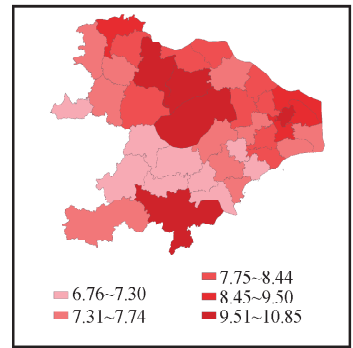

平均受教育年限/a

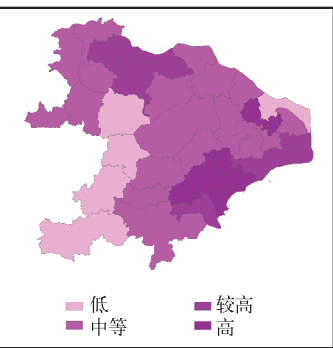

土地资源供给保障

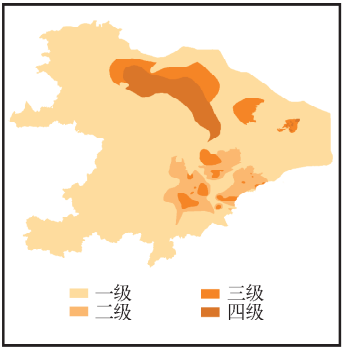

地面沉降

洪涝风险

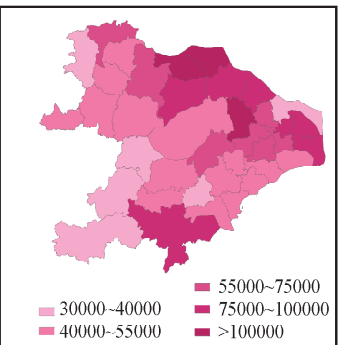

人均(GDP/元
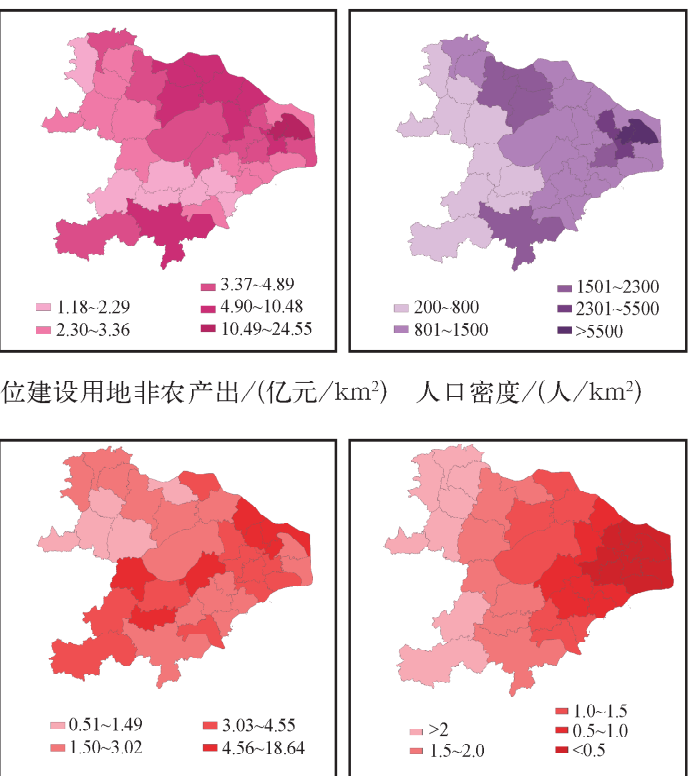

亿元GDP专利授权数/件

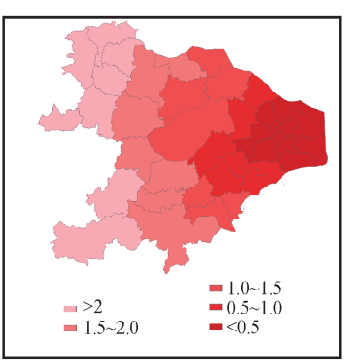

上海可达性 $/ \mathrm{h}$

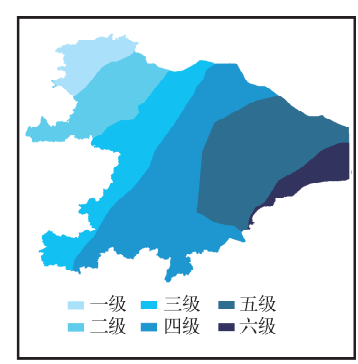

台风风险

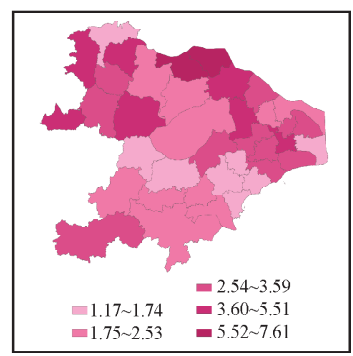

固定资产投人产出/亿元

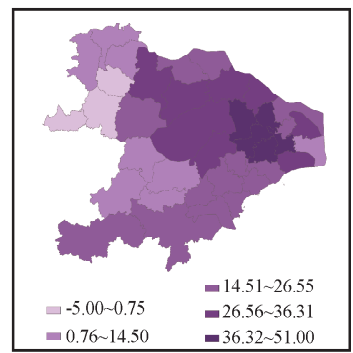

人口流动强度 $/ \%$

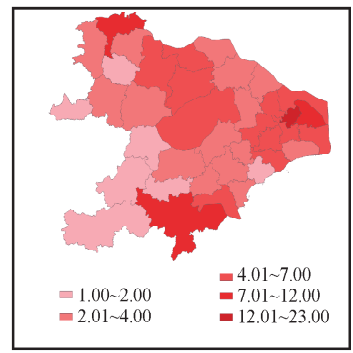

交通枢纽程度

图 3 空间开发适宜性评价指标

Fig. 3 The indicators of spatial potential development

设施及枢纽 (高速公路互通口、城际铁路和高速铁路站点、机场和港口) 的拥有程度来反映.

权重体现每个指标对评价目标的重要性和影响程度, 其确定要充分体现地区资源条件和经济发展的分 异特点和内在差异性, 其中自然生态要素着重考虑其可修复性和替代性, 经济社会要素考虑其导向性. 权重 的确定采用主观与客观相结合分析方法, 主观权重分析采用层次分析法, 客观权重分析主要采用熵值法, 权 重结果见表 1 . 
表 1 空间开发适宜性分区指标及权重

Tab. 1 The indicators and weights of spatial potential development

\begin{tabular}{llll}
\hline 系统层 & 因素层 & 指标层 & 权重 \\
\hline 资源环境承载力 & 生态重要性 & 极重要 & 0.1792 \\
& & 重要 & 0.0936 \\
& 灾害易损性 & 较重要 & 0.0488 \\
& 地面沉降 & 0.0987 \\
& 洪涝风险 & 0.0831 \\
& 台风风险 & 0.0189 \\
发展潜力 & 水资源供给保障 & 可利用水资源丰度 & 0.2012 \\
& 土地资源供给保障 & 可利用土地资源丰度 & 0.2765 \\
& 经济发展水平 & 人均 GDP & 0.1236 \\
& & 固定资产投人产出 & 0.0687 \\
& 劳动生产率 & 0.0455 \\
& 单位建设用地非农产出 & 0.0891 \\
& 人口集聚度 & 人口密度 & 0.1386 \\
& 人流动强度 & 0.0602 \\
& 平均受教育年限 & 0.1769 \\
& 亿元 GDP 专利授权数 & 0.1203 \\
& 上海可达性 & 0.0778 \\
& 交通枢纽程度 & 0.0993 \\
\hline & & \\
& & &
\end{tabular}

\section{2 综合评价方法}

采用逐级分层归并方法,将平行独立的各项指标加权求和,计算各单元的资源环境承载力指数和发展 潜力指数. 资源环境承载力方面, 总体上江苏沿江地区最高; 苏南南部地区、杭州湾北部地区也相对较高; 西 南部丘陵山地区最低. 发展潜力方面, 上海市区、杭州市区及靠近上海的近郊区县及苏锡大部分县市最高; 上海市其他郊县、江苏沿江大部市县相对较高; 西部和西南部山地丘陵地区大部分市县现状经济基础相对 薄弱、投人产出效益不高、区位和教育优势尚未体现,发展潜力相对较低 (图 4).
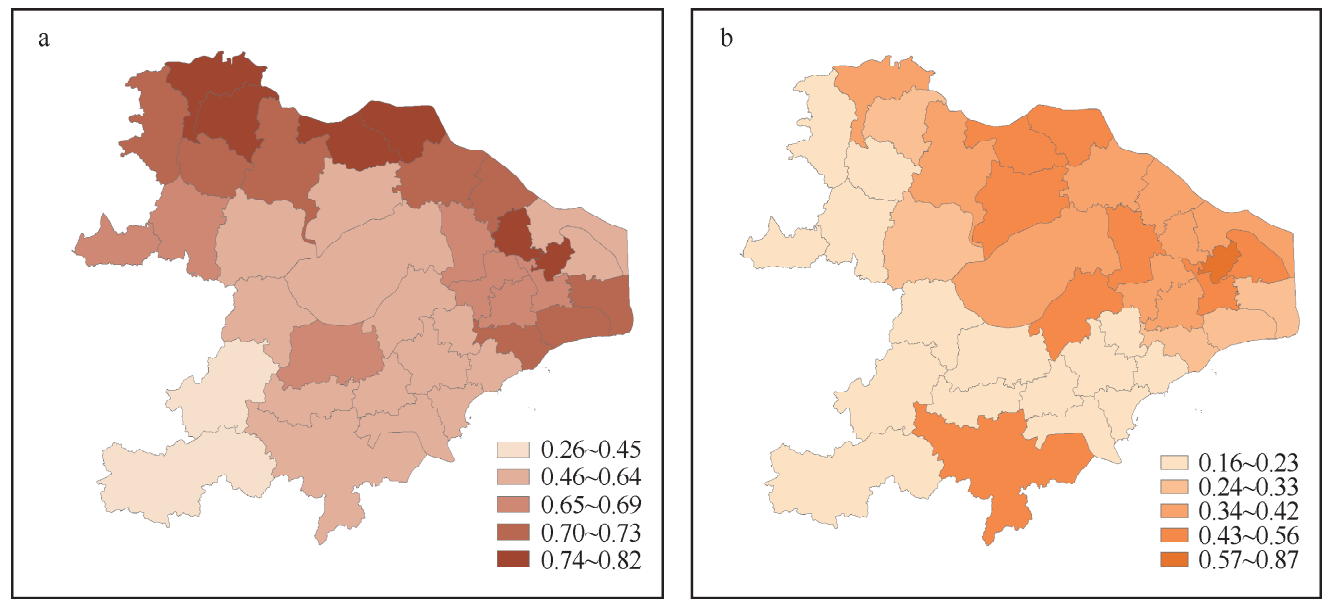

图 4 资源环境承载力 $(\mathrm{a})$ 和发展潜力 $(\mathrm{b})$

Fig. 4 Evaluation of carrying capacity on resource and environment(a) and development potential(b) 
从指标选择与组合来看, 资源环境承载力与发展潜力两类要素均为正向的引导性要素, 即该项因素分 值越高, 空间开发适宜性越强. 虽然空间开发适宜性是资源环境承载力和发展潜力合力作用的结果, 但是由 于两类要素的作用机理不同,不能简单采取加权求和方法,因此,本文采用矩阵向量模型计算适宜性指数. 矩阵向量模型中资源环境承载力指数和发展潜力指数分别被表示为一组向量, 指数值就表示其在空间开发 适宜性评价中贡献的能量, 即在合力作用中各自贡献的“分力”. 具体公式如下:

$$
P_{i}=\sqrt{\frac{1}{2}\left(\left[A_{i}\right]^{2}+\left[B_{i}\right]^{2}\right)}
$$

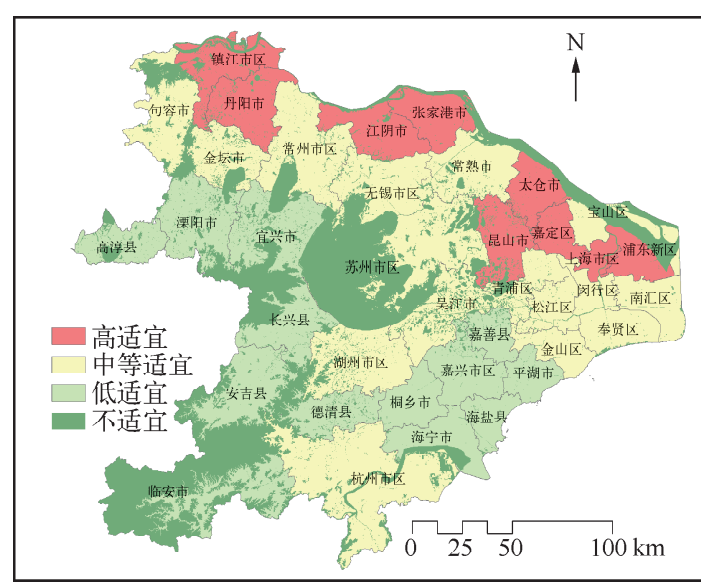

图 5 太湖流域空间开发适宜性分区

Fig. 5 The result of spatial potential development regionalization in Taihu Basin

式中, $P_{i}$ 表示 $i$ 单元的空间开发适宜性指数; $A_{i}$ 表示 资源环境承载力指数, $B_{i}$ 表示发展潜力指数. 对适 宜性指数采取聚类分析, 将太湖流域划分为高、中、 低三种适宜性类型区, 并将重要生态功能区划定为 不适宜开发区域. 高适宜性区域具有较高的经济社 会开发需求,同时受生态环境约束较低,适宜进行 大规模的工业开发和城市建设,或者适合大力发展 现代服务业,集聚城市人口,该区域主要包括上海 及其近郊地区和江苏沿江大部分地区等. 中等适宜 性区域是指具有较高的工业开发需求和开发效益, 但同时也受到一定的灾害风险影响, 在开发过程中 适度拓展发展空间, 提高土地利用效率, 注意生态 环境的保护,避免过度开发,主要包括沪宁沿线大 部分地区、杭州市区及上海南部地区等. 低适宜性 区域主要指资源环境承载力和发展潜力都不是很 高的区域,不适宜进行高强度的开发,需要控制开 发强度和内容, 实行有限度的发展, 主要分布于太

湖上游的山地丘陵区以及太湖东南部嘉兴大部分地区 (图 5). 不适宜开发区域主要指各级各类重要生态功 能保护区, 不宜在该区内进行任何有损生态环境的建设活动, 应增强生物群落的多样化,引导绿色空间相融 相通,禁止一切无关建设行为.

\section{3 空间失衡状态评估}

按照空间均衡理念, 不同适宜性区域空间开发导向及其建设用地配置强度要求是不同的, 资源环境承 载力高、发展潜力大的区域空间供给能力强, 相对适合高强度的建设用地开发, 相反则需要控制开发强度, 因此空间均衡程度可以理解为开发强度与空间供给能力 (开发适宜性) 的匹配程度. 匹配程度越低, 说明空 间失衡状态越明显. 本文以空间开发适宜性分区为基础, 根据不同单元的适宜性指数和开发强度, 采用 DEA 方法, 判断各单元的空间开发失衡程度.

DEA 方法运用运筹学的线性规划技术, 对不同决策单元的输人数据与输出数据的包络面的分析, 通过 判断不同决策单元的观察值与效率前沿的位置关系来研究效率问题. DEA 方法将所有决策单元输人输出变 量投射在效率空间中, 求出效率前沿, 此效率前沿是最有效率的单元点所连接而成的轨迹, 位于轨迹上的单 元点为输人输出组合最有效率, 其效率值为 1 ; 再利用决策单元的实际观察值与效率前沿的位置关系, 求出 不同决策单元的效率值. 对于本文来说, 决策单元即为分区评价单元, 输人数据为各单元空间开发适宜性指 数, 输出变量为各单元开发强度 (1), 若计算效率值高, 则表明开发强度与适宜性指数对应较好, 建设用地配置 与空间供给能力相对较为均衡, 效率值低则表明开发强度与单元的空间供给能力不够协调, 存在空间开发

(1) 考虑到太湖流域大型水面较多, 开发强度计算中国土面积不包括面积在 $50 \mathrm{~km}^{2}$ 以上的大型水面. 
失衡情况. 关于 DEA 方法的计算模型较多, 相关文献已有相关表述 ${ }^{[13-14]}$, 由于空间开发适宜性指数与建设 用地强度配置呈正相关关系，因此本文选用线性规划模型求解二者的效率对应关系.

评估结果表明,太湖流域空间开发强度与适宜 性总体较为协调, 空间开发均衡性较高. 若按照均 衡程度评估值进行聚类分析, 将所有单元划分为高 度均衡、基本均衡和相对失衡三种类型, 可以确定 评估值小于 0.4 的单元属于相对空间失衡单元 (表 2 ). 在这些单元中,金山区、湖州市区、太仓市、丹阳 市、句容市、金坛市、溧阳市等有一定的空间供给能 力, 资源环境承载力和发展潜力均相对较好, 但建 设用地开发强度较低, 属于相对开发不足的区域; 德清县、长兴县、安吉县、临安市空间供给能力较 差, 虽然其开发强度与其他单元相比相对不高, 但 与空间开发适宜性指数的匹配程度仍旧较低, 属于 空间开发过度区域.

\section{4 结论与讨论}

本文以流域单元为例,探讨跨省界尺度的空间 开发适宜性分区研究, 并以此为基础提出了空间开 发失衡状态定量评估方法, 研究结论基本符合太湖 流域空间开发的客观实际, 为促进流域经济社会可 持续发展提供了重要科学依据, 有利于协调流域空 间开发与生态环境建设, 对于未来合理有序进行流 域资源开发具有一定的指导意义. 按照空间开发失 衡评估方案,位于太湖下游的大部分地区和上游西 北部局部地区仍有一定的开发潜力, 可以适度扩大 生产和生活建设用地的规模, 保障基础设施和重点 项目建设,引导产业集中建设、集群发展, 同时要注 意提高土地利用与生态环境的协调程度, 尽量避免 改变水系格局的土地利用方式; 对于西南部上游生态 脆弱地区应严格限制建设用地数量的增加,积极挖潜、 盘活和优先使用存量建设用地, 支持基础设施、生态环 境建设、符合主体功能定位的优势特色产业用地, 将开 发强度控制在生态环境可承受的范围之内.

从研究方法来看, 数据包络分析方法能够较好 度量输人与输出变量之间的对应关系, 但各单元失 衡程度却依赖于效率前沿单元选择的精准性, 因此 对资源环境承载力和发展潜力评价指标和权重设置 提出了更高的要求, 需要进一步深化. 另一方面, 本 方法关于失衡性的评估结果只是基于实证区域封闭 的假设, 仅是区域内部各单元空间开发均衡程度的 相对高低排序. 此外, 本文解释了空间开发适宜性指 数与建设用地开发强度的数据匹配关系, 关于相互 间的作用机理及影响程度的定量研究仍可深人.

表 2 各单元空间开发失衡程度的 DEA 评估结果

Tab. 2 The evaluation results of spatial unbalance by DEA method

\begin{tabular}{|c|c|c|c|}
\hline 单元 & 适宜性指数 & 开发强度 & 效率值 \\
\hline 临安市 & 0.24 & 1.93 & 0.10 \\
\hline 安吉县 & 0.34 & 4.56 & 0.17 \\
\hline 长兴县 & 0.41 & 6.51 & 0.20 \\
\hline 平湖市 & 0.43 & 19.64 & 0.57 \\
\hline 嘉善县 & 0.44 & 18.62 & 0.53 \\
\hline 海盐县 & 0.45 & 18.64 & 0.52 \\
\hline 海宁市 & 0.45 & 19.32 & 0.54 \\
\hline 宜兴市 & 0.46 & 15.01 & 0.41 \\
\hline 嘉兴市区 & 0.46 & 21.08 & 0.57 \\
\hline 桐乡市 & 0.46 & 19.77 & 0.54 \\
\hline 德清县 & 0.46 & 9.48 & 0.26 \\
\hline 高淳县 & 0.49 & 9.99 & 0.26 \\
\hline 溧阳市 & 0.49 & 9.68 & 0.25 \\
\hline 湖州市区 & 0.50 & 14.62 & 0.37 \\
\hline 宝山区 & 0.51 & 40.56 & 1.00 \\
\hline 吴江市 & 0.51 & 20.68 & 0.51 \\
\hline 金坛市 & 0.51 & 11.67 & 0.29 \\
\hline 无锡市区 & 0.52 & 32.52 & 0.80 \\
\hline 苏州市区 & 0.52 & 34.27 & 0.83 \\
\hline 句容市 & 0.54 & 12.28 & 0.29 \\
\hline 青浦区 & 0.54 & 20.09 & 0.47 \\
\hline 松江区 & 0.55 & 26.32 & 0.60 \\
\hline 金山区 & 0.55 & 17.24 & 0.39 \\
\hline 杭州市区 & 0.56 & 21.41 & 0.49 \\
\hline 奉贤区 & 0.56 & 18.50 & 0.42 \\
\hline 常熟市 & 0.56 & 18.33 & 0.41 \\
\hline 南汇区 & 0.56 & 20.89 & 0.47 \\
\hline 常州市区 & 0.57 & 27.19 & 0.60 \\
\hline 闵行区 & 0.58 & 49.40 & 1.00 \\
\hline 太仓市 & 0.58 & 15.78 & 0.34 \\
\hline 昆山市 & 0.60 & 20.95 & 0.44 \\
\hline 浦东新区 & 0.60 & 43.21 & 1.00 \\
\hline 嘉定区 & 0.61 & 37.21 & 0.78 \\
\hline 丹阳市 & 0.61 & 16.20 & 0.34 \\
\hline 镇江市区 & 0.62 & 22.16 & 0.45 \\
\hline 张家港市 & 0.62 & 25.65 & 0.52 \\
\hline 江阴市 & 0.62 & 24.92 & 0.50 \\
\hline 上海市区 & 0.82 & 96.86 & 1.00 \\
\hline
\end{tabular}




\section{5 参考文献}

[ 1 ] Budhendra B, Jon H, Bernie E et al. Assessing watershed-scale, long-term hydrologic impacts of land-use change using a GIS-NPS model. Environmental Management, 2003, 26(6) : 643-658.

[2] 严金明. 土地管理应有理性思维. 河南国土资源, 2005，(7): 8-9.

[3] 柇 杰. 我国主体功能区划的科学基础. 地理学报, 2007, 62(4):339-350.

[4] 孙 伟, 陈 雯. 市域空间开发适宜性分区与布局引导研究一一以宁波市为例. 自然资源学报, 2009, 24(3): 402-413.

[ 5 ] 陈 雯, 孙 伟, 赵海霞. 区域发展的空间失衡模式与状态评估一一以江苏省为例. 地理学报, 2010, 65(10): 1209-1217.

[6] 陈 雯, 孙 伟, 段学军等. 苏州地域开发适宜性分区. 地理学报, 2006, 61(8): 839-846.

[ 7 ] 顾朝林, 张晓明, 刘晋媛等. 盐城开发空间区划及其思考. 地理学报, 2007, 62(8): 787-798.

[8] 陆玉麒, 林 康, 张 莉. 市域空间发展类型区划分的方法探讨. 地理学报, 2007, 62(4): 351-363.

[9] 陈 雯, 孙 伟, 段学军等. 以生态-经济为导向的江苏省土地开发适宜性分区. 地理科学, 2007, 27 (3): 312-317.

[10] 曹有挥, 陈 雯, 吴 威等. 安徽沿江主体功能区划分研究. 安徽师范大学学报: 自然科学版, 2007, 30(3): 383-389.

[11] 朱传耿, 仇方道, 马晓冬等. 地域主体功能区划理论与方法的初步研究. 地理科学, 2007, 27(2): 136-141.

[12] Sarkis J. An analysis of the operational efficiency of major airports in the United States. Journal of Operations Management, 2000, 18(3) : 335-351.

[13] 林 勇, 许秀丽. 基于数据包络分析的区域全要素能源效率分析. 生态经济, 2010, (8): 60-62.

[14] 王学渊. 基于数据包络分析方法的灌溉用水效率测算与分解. 农业技术经济, 2009，(6)：40-49.

[15] 王栋等. 生态疏浚对太湖五里湖湖区生态环境的影响. 湖泊科学, 2005, 17(3) : 263-268.

[16] 顾 岗, 陆根法. 太湖五里湖水综合整治的设想. 湖泊科学, 2004, 16(1): 56-60.

[17] 黄宣伟. 论《太湖流域综合治理规划》的得失. 湖泊科学, 2002, 14(3) : 205-208.

[18］杨桂山. 流域综合管理导论. 北京: 科学出版社, 2004. 